\title{
ANALYTICAL STUDY OF BEHAVIOR OF CONCRETE FILLED DOUBLE-SKIN AND DOUBLE-TUBE HOLLOW STEEL COLUMN UNDER CYCLIC LOAD
}

\author{
Onkar Harishchandra Lohar \\ Department of Applied Mechanics \\ GCEK, Karad, Maharashtra, India
}

\author{
Prof. V. M. Bogar \\ Department of Applied Mechanics \\ GCEK, Karad, Maharashtra, India
}

\begin{abstract}
R.C.C. column is commonly used in construction industry and use CFST over it become very advantageous. CFST member have good stiffness and strength as compared to conventional R.C.C. member. The main disadvantage of CFST is that they subjected to serious damage under cyclic load, mostly in earthquake prone areas where resistance is important. Now days, many researchers exploring the information about the concrete filled double-skin hollow steel (CFDSHS) and concrete filled double-tube hollow steel (CFDTHS) column. Various study is carried out and continuing for both to decrease the self-weight of composite structures and minimize earthquake effects. The purpose of this study is to study the behavior of concrete filled double-skin and double-tube hollow steel column under cyclic load with different sections. For this study ANSYS WORKBENCH software was used for numerical simulation of sections. Six models were created using software with different section size and analyzed under cyclic load with constant axial load.
\end{abstract}

\section{Keywords-CFDSHS, CFDTHS, ANSYS.}

\section{INTRODUCTION}

R.C.C. column is commonly used in construction industry and use CFST over it become very advantageous. CFST member have good stiffness and strength as compared to conventional R.C.C. member. Steel-concrete composite structures have great advantage in tall buildings construction, bridge construction and transmission towers due to their higher load-carrying capacity and stiffness which results from combining the rigidity of reinforced concrete with structural steel sections. Outer hollow steel performs like formwork and also work like reinforcement for the concrete. The local buckling of hollow steel is reduced by concrete and section ductility increases. The main disadvantage of CFST is that they subjected to serious damage under cyclic load, mostly in earthquake prone areas where resistance is important.

Now days, many researchers exploring the information about the concrete filled double-skin hollow steel (CFDSHS) and concrete filled double-tube hollow steel (CFDTHS) column. The two concentric steel tubes with concrete between them, known as a concrete-filled double-skin hollow steel (CFDSHS) column. They performed similar as CFST columns but with lower self-weight and higher stiffness. CFDTHS column in which the inner tube and space between the tubes is filled with concrete. This type of column has large strength and stiffness and is called a concrete-filled double-tube hollow steel (CFDTHS) column. The load-bearing capacity of this column is high because of the double concrete core.

Several study is carried out and continuing for both to decrease the self-weight of composite structures and minimize earthquake effects, and some literature reviews were done by Schneider et al.(1998) and Han et al. $(2005,2006,2011,2017)$.

The main objective of this paper is to study the behavior of concrete filled double-skin and double-tube hollow steel column under cyclic load with different sections. For this analytical study six members were created using software with different diameter-to-thickness $(\mathrm{D} / \mathrm{t})$ ratio and analyzed under increasing cyclic load subjected to constant axial load.

\section{ANALYTICAL PROGRAM}

For analytical simulation six models were created using different diameter-to-thickness ratio. Then these members were performed in FE software named ANSYS Workbench.

\section{A. Section size}

Six models in which three are of CFDSHS and three are of CFDTHS were created with three different outer and inner diameter-to-thickness ratios which is shown in table no. 1. In the process of selection of section size of members, criteria to prevent the premature buckling effect of steel hollow specimens referenced in EC4 were kept in mind which is given by following eq. (1)

$$
\frac{D}{t} \leq 90 \frac{235}{f y}
$$

\begin{tabular}{|c|c|c|c|c|c|c|}
\hline $\begin{array}{c}\text { Sr. } \\
\text { no. }\end{array}$ & $\begin{array}{c}\text { Specimen } \\
\text { ID }\end{array}$ & $D_{o}$ & $t_{o}$ & $D_{i}$ & $t_{i}$ & $\mathrm{~L}$ \\
\hline
\end{tabular}


International Journal of Engineering Applied Sciences and Technology, 2020

Vol. 5, Issue 6, ISSN No. 2455-2143, Pages 223-227

Published Online October 2020 in IJEAST (http://www.ijeast.com)

\begin{tabular}{|c|l|c|c|c|c|c|}
\hline & & $(\mathrm{mm})$ & $(\mathrm{mm})$ & $(\mathrm{mm})$ & $(\mathrm{mm})$ & $(\mathrm{mm})$ \\
\hline 1 & CFDTHS1 & 165.1 & 5.4 & 76.1 & 4.5 & 700 \\
\hline 2 & CFDTHS2 & 168.3 & 5.4 & 88.9 & 4.8 & 700 \\
\hline 3 & CFDTHS3 & 193.7 & 5.9 & 114.3 & 5.4 & 700 \\
\hline 4 & CFDSHS1 & 165.1 & 5.4 & 76.1 & 4.5 & 700 \\
\hline 5 & CFDSHS2 & 168.3 & 5.4 & 88.9 & 4.8 & 700 \\
\hline 6 & CFDSHS3 & 193.7 & 5.9 & 114.3 & 5.4 & 700 \\
\hline
\end{tabular}

Table 1. Section sizes of members

For above size diameter-to-thickness ratios were calculated and compared as per eq. (1) and are given in table no. 2

\begin{tabular}{|c|c|c|c|c|}
\hline $\begin{array}{l}\text { Sr. } \\
\text { no. }\end{array}$ & Specimen ID & $D_{o} / t_{o}$ & $D_{i} / t_{i}$ & $90(235 / f y)$ \\
\hline 1 & CFDTHS1 & 30.57 & 16.9 & 50.96 \\
\hline 2 & CFDTHS2 & 31.167 & 18.52 & 50.96 \\
\hline 3 & CFDTHS3 & 32.83 & 21.167 & 50.96 \\
\hline 4 & CFDSHS1 & 30.57 & 16.9 & 50.96 \\
\hline 5 & CFDSHS2 & 31.167 & 18.52 & 50.96 \\
\hline 6 & CFDSHS3 & 32.83 & 21.167 & 50.96 \\
\hline
\end{tabular}

Table 2. Diameter-to-thickness ratios

\section{B. Material properties}

The steel used in this analysis is according to IS $1786: 2008$ with chemical composition of carbon- $0.30 \%$, sulphur- $0.06 \%$, phosphorus- $0.06 \%$, sulphur+phosphorus (S+P)- $0.11 \%$, and carbon equivalent $-0.42 \%$. The yield strength, ultimate strength, elastic modulus, Poisson's ratio and density of the steel are $415 \mathrm{MPa}, 489 \mathrm{MPa}, 210 \mathrm{GPa}, 0.3$ and $7850 \mathrm{~kg} / \mathrm{m}^{3}$ respectively.

One type of concrete was used with cube strength $(f c u)$ at 28 days is $60 \mathrm{MPa}$.

\section{Boundary conditions and loading}

The bottom end of the model is fixed by fixed support option in ANSYS and the top end of the model is kept as free.

Axial load of $700 \mathrm{kN}$ and cyclic load are applied at top face of the section in downward and lateral direction respectively. The cyclic loading history consisted increasing cycles under displacement control. Fig. 1 shows the loading history of cyclic load

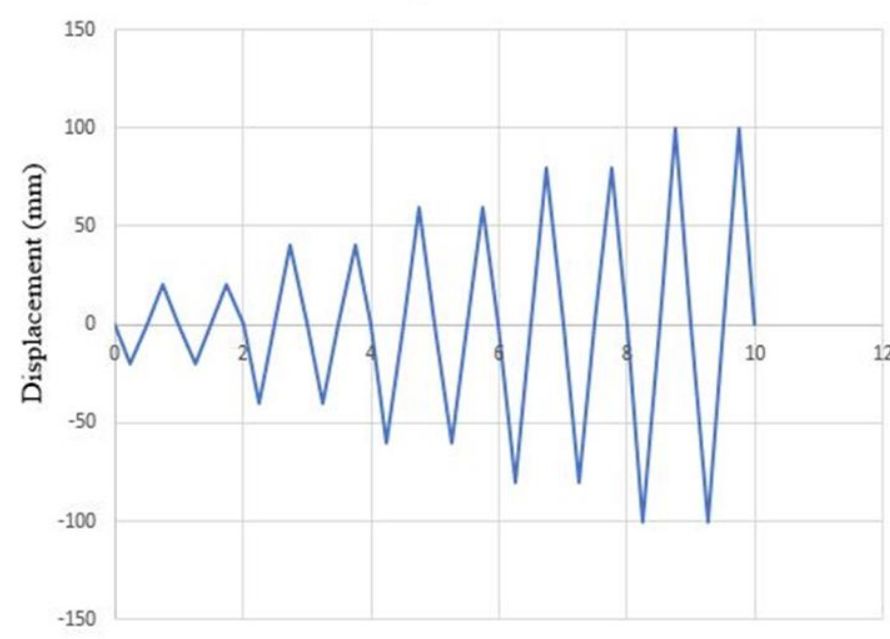

Fig. 1 Loading history

\section{Geometry and meshing}

Geometry is done in DesignModeler software and then it is meshed in ANSYS WB software. The fig. 2 shows meshed view of both members.

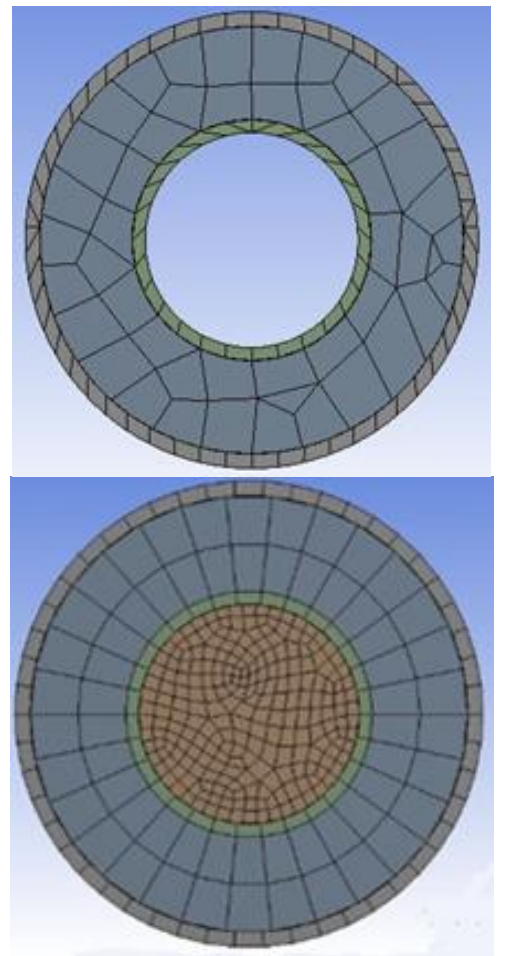

Fig. 2 Meshed view

III. ANALYSIS AND RESULT

The six specimen which are created were analyzed with mentioned boundary condition and loading. Fig. 3 shows the results. 


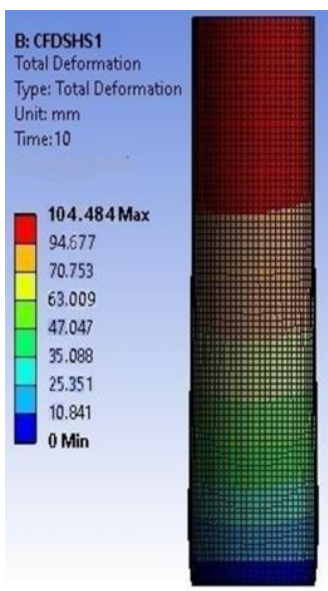

(a). CFDSHS1

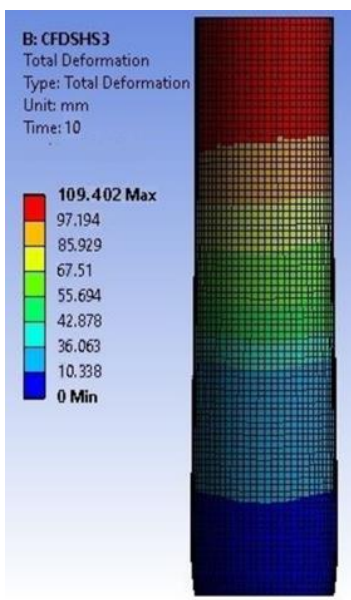

(c). CFDSHS3

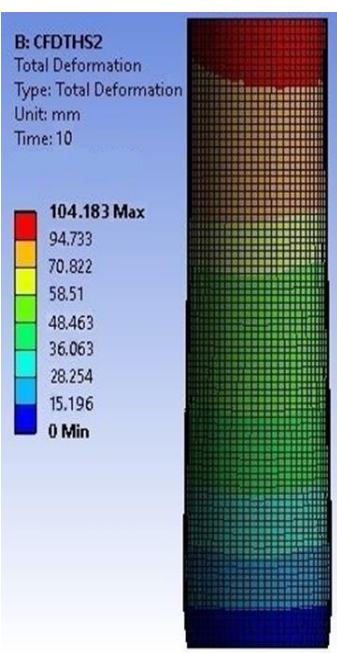

(e). CFDTHS2

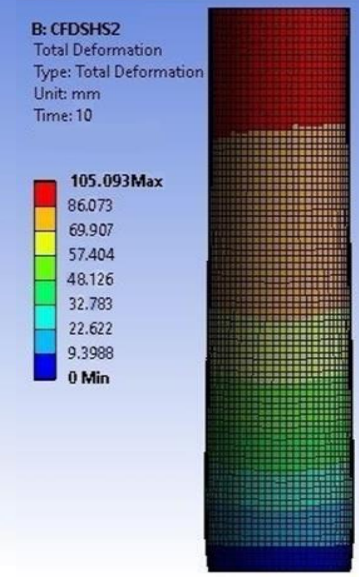

(b). CFDSHS2

(d). CFDTHS1
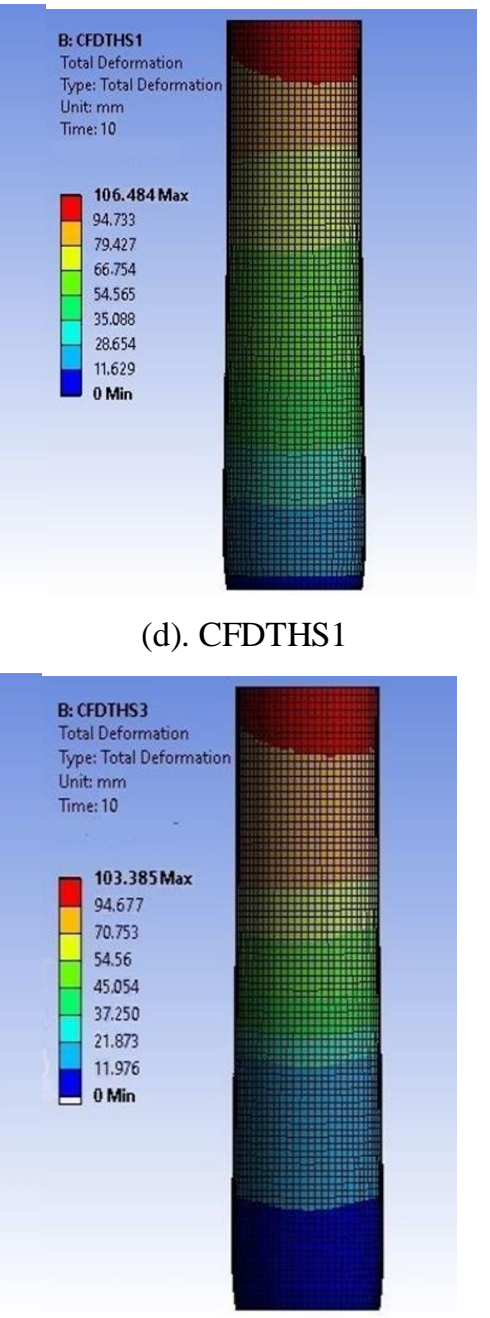

(f). CFDTHS3

Fig. 3 Results of the members

It was seen that when cyclic loading apply, the maximum displacement occur at every individual cycle. The analyzed curves of lateral load $(\mathrm{P})$ versus the displacement $(\Delta)$ curves (which are also called hysteresis curves) for both columns are shown in fig. 4.

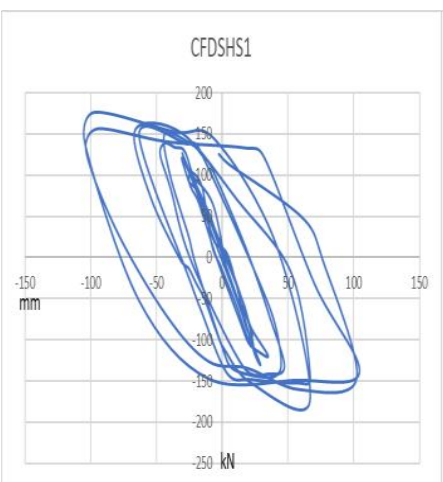

(a). CFDSHS1

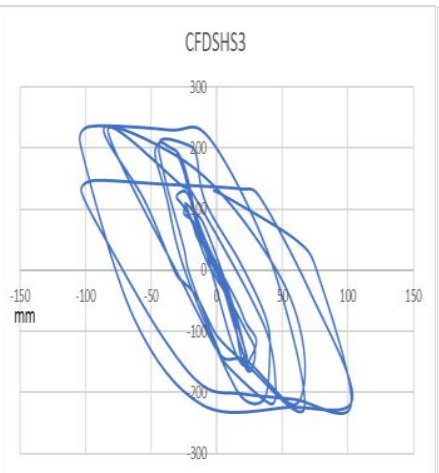

(c). CFDSHS3

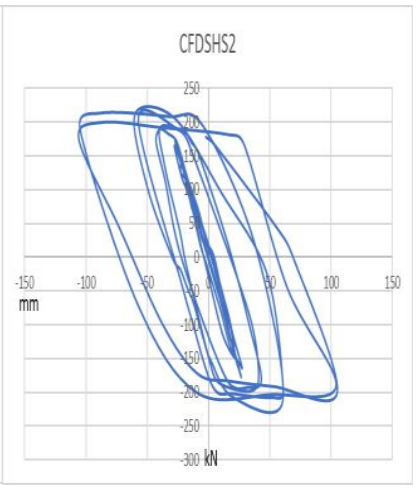

(b). CFDSHS2

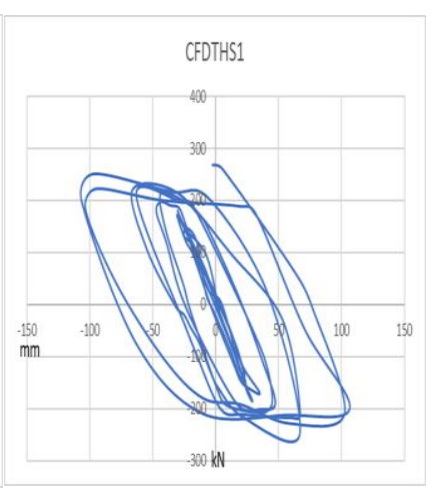

(d). CFDTHS1

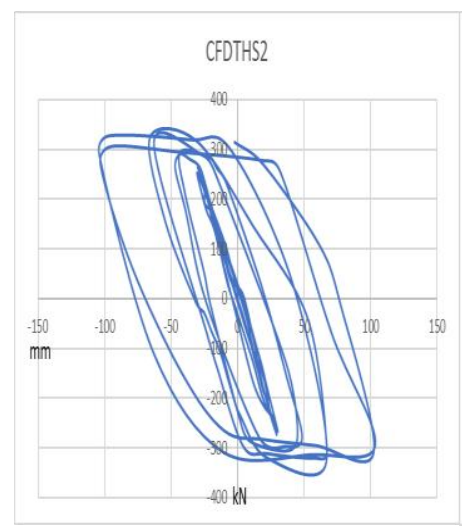

(e). CFDTHS2

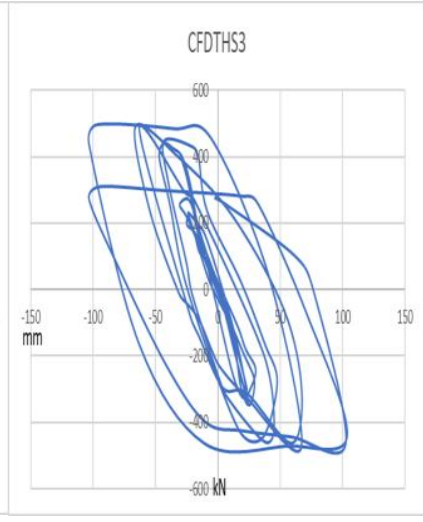

(f). CFDTHS3
Fig. 4 Hysteresis curve

The load versus displacement envelop curves (skeleton curves) for all columns are shown in fig. 5. Now days, most skeleton curves are obtained by connecting the maximum peak points of the member hysteresis curves. 


\section{CFDSHS1}

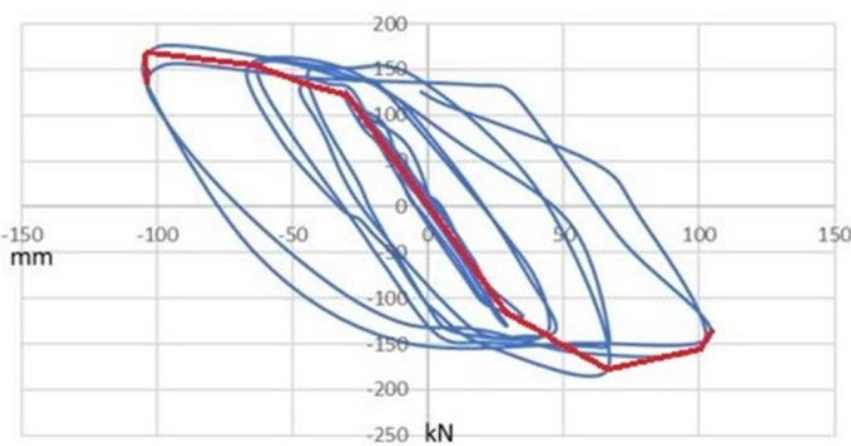

(a). CFDSHS 1

CFDSHS2

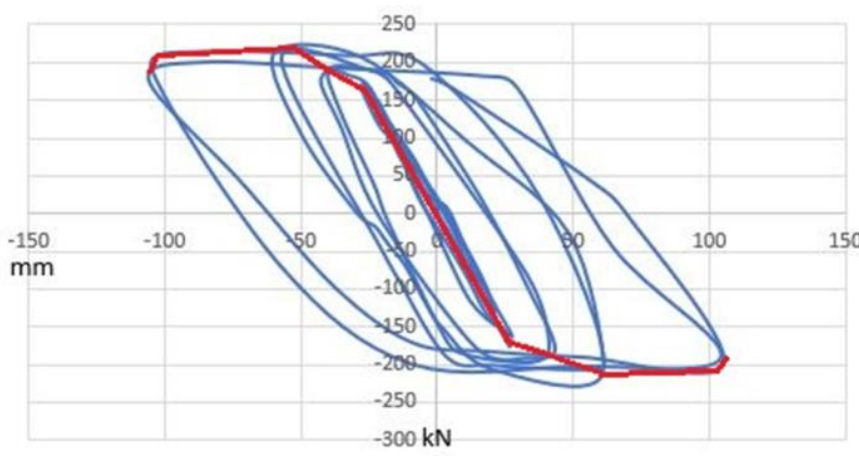

(b). CFDSHS2

CFDSHS3

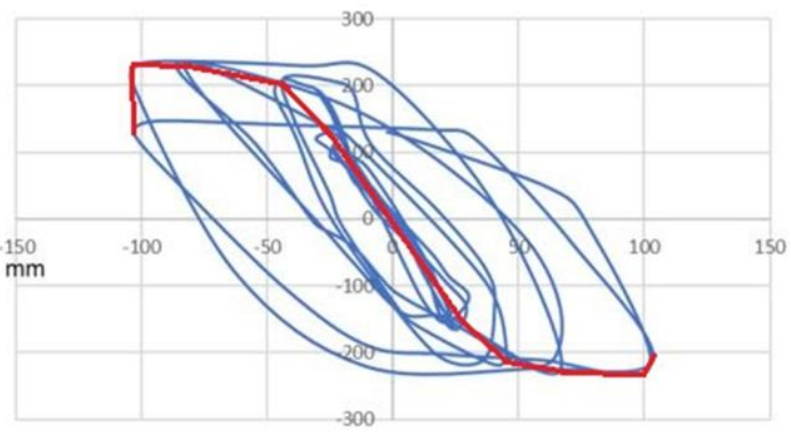

(c). CFDSHS3

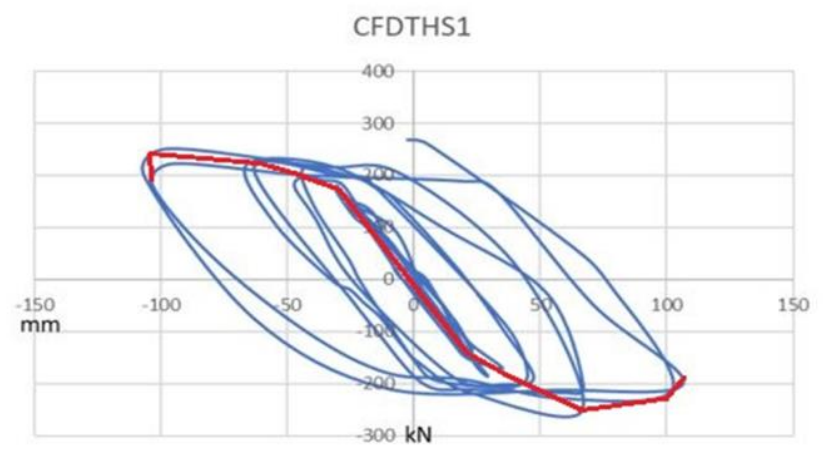

(d). CFDTHS1

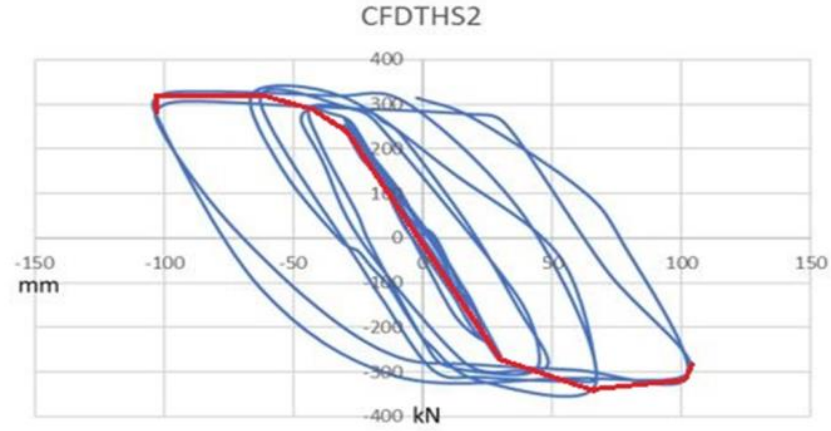

(e). CFDTHS2

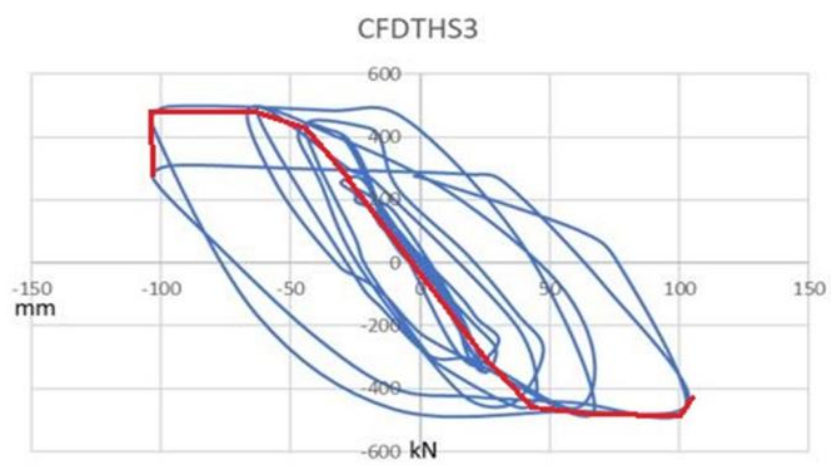

(f).CFDTHS3

Fig. 5 Skeleton curves

\section{CONCLUSION}

In this study concrete-filled double-skin hollow steel (CFDSHS) and concrete-filled double-tube hollow steel (CFDTHS) column sections were studied using numerical analysis in ANSYS WB software. A total of six different models were analysed under similar boundary conditions and similar loading pattern. Throughout the study size of column sections was changed. Based on all above results following conclusions are drawn.

(1). The behaviour of hysteresis curve for all columns is almost similar this is due to the parameters like D/t ratio, length of the column, material assigned to different sections, boundary condition and loading is similar. The hysteresis loop becomes increasingly get larger as the size of columns increases.

(2). As the hysteresis curve covered large area as size were increased, it indicates energy dissipated capacity for column increased with size.

(3). As the hysteresis curve get larger the skeleton curve gets increased. The load carrying capacity increases as skeleton curve increased..

(4). The load carrying capacity of the concrete-filled doubletube hollow steel (CFDTHS) column is more than the concrete-filled double-skin hollow steel (CFDSHS) column. 


\section{International Journal of Engineering Applied Sciences and Technology, 2020 \\ Vol. 5, Issue 6, ISSN No. 2455-2143, Pages 223-227 \\ Published Online October 2020 in IJEAST (http://www.ijeast.com)}

This is mainly due to the present on inner core in CFDTHS column.

\section{REFERENCE}

[1] Yufen ZHANG, Junhai ZHAO and Weifeng YUAN.(2013), "Study on compressive bearing capacity of concrete-filled square steel tube column reinforced by circular steel tube inside," JOURNAL OF CIVIL ENGINEERING AND MANAGEMENT, (pp. 787-795).

[2] Y.H. Wang, G.B. Lu and X.H. Zhou.(2018), "Experimental study of the cyclic behavior of concretefilled double skin steel tube columns subjected to pure torsion," Thin-walled Structures, (pp. 425-438).

[3] M.F. Hassanein, O.F. Kharoob and L. Gardner.(2015), "Behavior and design of square concrete-filled double skin tubular columns with inner circular tubes," Engineering Structures, (pp. 410-424).

[4] Farahi M., Heirdarpour A, Zhao XL and Al-Mahaidi R.(2016), "Compressive behaviour of concrete-filled double-skin sections consisting of corrugated plates," Engineering Structures, (pp. 467-477).

[5] A. Duarte, B. Silva, J. de Brito, E. Júlio and J.M. Castro(2016), "Experimental study on short rubberized concrete-filled steel tubes under cyclic loading," Composite Structures, (pp. 394-404).

[6] Feng Zhou and Wenchao Xu.(2016), "Cyclic loading tests on concrete-filled double-skin (SHS outer and CHS inner) stainless steel tubular beam columns," Engineering Structures, (vol. 127, p. 304-318).

[7] Lin-Hai Han, Hong Huang, Zhong Tao and Xiao-Ling Zhao.(2006), "Concrete-filled double skin steel tubular (CFDST) beam-columns subjected to cyclic bending," Engineering Structures, (vol. 28, p. 1698-1714).

[8] You-Fu Yang, Chao Hou and Min Liu.(2018), "Experimental Study and Numerical Analysis of CFSST Columns Subjected to Lateral Cyclic Loading," Journal of Structural Engineering,(pp. 04018219(1)04018219(16)).

[9] Aline L. Camargo, João Paulo C. Rodrigues, Ricardo H. Fakury and Luis Laim.(2019), "Fire resistance of axially and rotationally restrained concrete-filled double-skin and double-tube hollow steel columns," Journal of
Structural Engineering,(pp. 04019128(12)).

[10] Yi Hu, Junhai Zhao, Dongfang Zhang and Yanxiong Chen.(2019), "Seismic behavior of concrete-filled double-skin steel tube/moment-resisting frames with beam-only-connected precast reinforced concrete shear walls," Archives of civil and mechanical engineering, (pp. 967-980).

[11] Han LH and Yang YF.(2005), "Cyclic performance of concrete-filled steel CHS columns under flexural loading," Journal of Constructional Steel Research, (pp. 423-52).

[12] Liao, F. Y., LH. Han, Z. Tao and K. J. R. Rasmussen.(2017), "Experimental behavior of concretefilled stainless steel tubular columns under cyclic lateral loading," Journal of Structural Engineering, (pp. 04016219).

[13] Han. LH., S. H. He, F. Y. Liao and Z. Tao.(2011), "Performance and calculations of concrete filled steel tubes (CFST) under axial tension," Journal of Constr. Steel Res, (pp. 1699-1709).

[14] Schneider SP.(1998), "Axially loaded concrete-filled steel tubes," Journal of Structural Engineering, ASCE,(p. 1125-38.) 